\title{
"The effect of a new wave of COVID-19 on the stock market performance: Evidence from the twenty JSE listed companies in South Africa"
}

\begin{tabular}{|c|c|}
\hline AUTHORS & $\begin{array}{l}\text { Gbenga Wilfred Akinola (iD) } \\
\text { Keji Sunday Anderu (iD) } \\
\text { Josue Mbonigaba (iD) } \\
\mathbb{R}\end{array}$ \\
\hline ARTICLE INFO & $\begin{array}{l}\text { Gbenga Wilfred Akinola, Keji Sunday Anderu and Josue Mbonigaba (2021). The } \\
\text { effect of a new wave of COVID-19 on the stock market performance: Evidence } \\
\text { from the twenty JSE listed companies in South Africa. Investment Management } \\
\text { and Financial Innovations, 18(4), 67-79. doi:10.21511/imfi.18(4).2021.07 }\end{array}$ \\
\hline DOI & http://dx.doi.org/10.21511/imfi.18(4).2021.07 \\
\hline RELEASED ON & Wednesday, 20 October 2021 \\
\hline RECEIVED ON & Saturday, 26 June 2021 \\
\hline ACCEPTED ON & Monday, 11 October 2021 \\
\hline LICENSE & $\begin{array}{l}(c) E Y \\
\text { This work is licensed under a Creative Commons Attribution } 4.0 \text { International } \\
\text { License }\end{array}$ \\
\hline JOURNAL & "Investment Management and Financial Innovations" \\
\hline ISSN PRINT & $1810-4967$ \\
\hline ISSN ONLINE & $1812-9358$ \\
\hline PUBLISHER & LLC "Consulting Publishing Company "Business Perspectives" \\
\hline FOUNDER & LLC "Consulting Publishing Company "Business Perspectives" \\
\hline
\end{tabular}

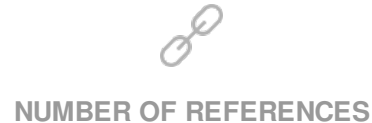

25

\section{NUMBER OF FIGURES}

24
=:ニ

NUMBER OF TABLES

3

(C) The author(s) 2021. This publication is an open access article. 


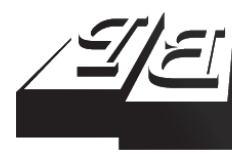

BUSINESS PERSPECTIVES

(O)

LLC "CPC "Business Perspectives" Hryhorii Skovoroda lane, 10, Sumy, 40022, Ukraine www.businessperspectives.org
Received on: $26^{\text {th }}$ of June, 2021 Accepted on: $11^{\text {th }}$ of October, 2021 Published on: $20^{\text {th }}$ of October, 2021

(C) Gbenga Wilfred Akinola, Keji Sunday Anderu, Josue Mbonigaba, 2021

Gbenga Wilfred Akinola, Ph.D. Dr., School of Accounting, Law and Management Faculty, Economics and Finance Department, University of KwaZulu-Natal, South Africa. (Corresponding author)

Keji Sunday Anderu, School of Accounting, Economics, and Finance, College of Law and Management, University of KwaZulu-Natal, South Africa.

Josue Mbonigaba, Ph.D., School of Accounting, Economics, and Finance, College of Law and Management, University of KwaZulu-Natal, South Africa.
Gbenga Wilfred Akinola (South Africa), Keji Sunday Anderu (South Africa), Josue Mbonigaba (South Africa)

\section{THE EFFECT OF A NEW WAVE OF COVID-19 ON THE STOCK MARKET PERFORMANCE: EVIDENCE FROM THE TWENTY JSE LISTED COMPANIES IN SOUTH AFRICA}

\begin{abstract}
The lockdown shocks resulting from the global pandemic of COVID-19 in March 2020 brought untold economic imbalance to the financial sector in South Africa. The government's proactive alternative measure of control to the new wave of COVID-19 must be investigated to offer policy suggestions for future economic and financial planning. Consequently, this study investigated the impact of the new wave of COVID-19 on the financial market with a special interest in the twenty JSE listed companies in South Africa. To enhance the quality in the frequency of study, daily panel data from November 2020 to January 2021 were sourced from S\&P Capital IQ and Google online. The impact of COVID-19 was investigated alongside other variables that can influence the return of the stock markets on twenty JSE listed companies. The variables under investigation are daily exchange rate (dollar terms), dividend-adjusted share pricing, daily COVID-19 infection rate. Both robust descriptive and fixed effects time-variant analyses were adopted as the estimating techniques. The study provided empirical evidence that there is a direct but slow link between the daily incidence of infectious COVID-19 and returns on the stock market as key variables. This positive relationship indicates that both COVID-19 and financial activities could co-habit together to enhance greater return on the stock in South Africa. Hence, lockdown may not be most appropriate to the national economy of South Africa.
\end{abstract}

\section{Keywords}

COVID-19, pandemic, panel-data, fixed-effects, cohabit, economy

JEL Classification G12, I10

\section{INTRODUCTION}

The financial market in South Africa is one of the most developed markets in the continent of Africa. Along with this development, there is the financial crisis bedeviling the economy over the years. South African economy has been faced with numerous downturns in the past two decades, which include the Asian crisis of 1998, the bubble collapse and currency crunch of 2001, the world financial crisis (GFC) in 2008, the renegade and European Monetary Crisis of 2016 , and nowadays the COVID-19 pandemic. The contraction of the South African economy from $5 \%$ to as little as $-23.5 \%$ has been predicted by experts for 2020 with certain industries to be more severely affected than others (PWC, 2021). The incidences of novel coronavirus cut across the different sectors of the economy and this has drastic effects on the 2020 South African economic outlook as predicted by the experts (OECD, 2020). The background problem of this study is that in the past, the financial market responded to unforeseen incidences such as a pandemic outbreak or financial crisis. Findings have shown that in both cases of the pandemic outbreak and financial crisis, finan- 
cial markets had not been immune against financial shocks. Consequently, the financial market in most cases reacted differently to unexpected occurrences. This study investigates whether the South African financial market is immune to the current surge of coronavirus disease. This emerging concern baffles regulators and investors and there is the need for quick answers to inform them of the nature of the market reactions through available data.

It is worthy to note that few studies like Horowitz (2020), Gormsen and Koijen (2020), and Ngwakwe (2020) have recently tried to come up with different inferences on how the financial market responded to the COVID-19 pandemic but most of these pieces of evidence are from different economies outside South Africa, which show the novelty of this study.

The motive behind the choice of South Africa is because its economy is one of the countries with high incidences of COVID-19, which would to some extent reveal the relevant pieces of evidence on how the new wave of the pandemic has influenced the South African financial market performances within the period under review. The sampled twenty JSE listed companies are market leaders in South Africa, hence a justification for their selection. Interestingly, the findings from this study could serve as a future guide for both investors and multinational agencies such as World Health Organization, World Bank, World Trade Organization, International Monetary Fund, and the South African government research institutes.

\section{LITERATURE REVIEW AND HYPOTHESIS}

There are various theoretical contributions to the effects of coronavirus outbreaks on stock market performances. Theriou et al. (2006) argued that CAPM analyses the disparity between expected asset returns and systemic risks as affected by investors in line with current circumstances in the global financial market. The COVID-19 pandemic has strongly been linked with economic recession global. Theoretically, the impact of the COVID-19 pandemic could be viewed from the perspective of demand and supply shock: (1) aggregate supply was perturbed by the global supply chains disruption, the decline in the supply of labor force was orchestrated by social distancing and quarantine, (2) aggregate demand caused by the lockdown was also disrupted from multiple dimensions. The decline in the consumption of durable goods (household appliances, cars, consumer electronics), services (tourism, restaurants), and the uncertainty surrounding the spread of the disease-causing households, firms, and organizations increased their precautionary savings in order to curtail consumption. This uncertainty condition also causes some informal workers or non-permanent, to lose income thereby leading to the reduction in consumption, and this uncertainty adversely affected firms' liquidity and consequently stopping investment (Lanchimba et al., 2020).
Therefore, CAPM together with demand and supply shock theories serve as the bedrock to this study and they shall be put into context to fill the spotted gap identified in this study.

South African financial markets efficiently facilitate the direct movement of investment and assets in an economy. It enhances the accumulation of capital and the production of goods and services through the activity of the stock exchange market. The market makes a direct contribution to the South African economy through its value-added contribution to Gross Domestic Product, taxation payment, and employment creation. However, risk effects resulting from the influence of the COVID-19 disease on the financial market require the right application and the understanding of the capital asset pricing model to better explain the theoretical foundation of the concept under investigation.

CAPM defines the association between systematic risk and anticipated return for assets, especially stocks. This is widely adopted in the field of finance for pricing uncertain stocks and creating anticipated earnings for assets due to the risk of these assets and capital cost (Theriou et al., 2006). Many factors may constitute risk factors to the financial market. Notably, within the recent global financial experiences, the COVID-19 pandemic has been identified. The implication is that the COVID-19 
outbreak has constituted a risk factor capable of slowing down the rate of return in investment, which is not a foreseeable adventure by the investors. The market is assumed to be competitive that would spur a rise in capital market aggregate line while the risk is achieved. The capital asset pricing model is developed via the Lagrangian multipliers method. In this case, flat risk gains are being forgone along the risk calculated by parameter estimates, probably non-changeable risk. Whereas the priced risk at the market interjection point is the risk that cannot be spread away. CAPM is propounded concerning the comparatively controlled theoretical framework. Therefore, it paved way for the linear systemic link between returns and risk in the capital market. This theoretical model better explains the explanatory variables that intuitively fit into the measurement of the effect of the novel coronavirus wave on the security market returns of twenty listed companies in South Africa.

To test the application of the foregoing theory, empirical studies have emerged in the literature. Vividly, the historical performance of the stock market has emerged through various scholarly literature that addresses the impact of different outbreaks such as influenza, flu, SARS among others on the general performance of the stock market. For instance, Chen et al. (2007) posit that SARS incidence in 2003 weakened Taiwanese hotel stock performance. Severe Acute Respiratory Syndrome distorted district stock markets performance in the Asian sub-region economies (Chen et al., 2018). The stringent and stricter lockdown measures, within and outside the national borders, drove a bigger drop in the country's stock prices, though with a more major drastic influence on the stock market transactions in the US than in China (Davis et al., 2021). Therefore, it is pertinent for major actors in developing economies to put up "build back better" for sustainable economic output through domestic resource mobilization (OECD, 2020).

Another related finding on the effect of the COVID-19 endemic on global security market prices by Muhammad et al. (2020) disclosed that the novel corona outbreak has significant effects on corporate sectors' performances. The study explored secondary data analysis through Ordinary Least Square (OLS) from stock mar- kets data obtained across China, Pakistan, the United Kingdom, Japan, Iran, Italy, South Africa, the United State of America, and Spain. It was revealed that there was a sharp drop in the financial positions of the selected countries due to distortions in the stock market activities as a result of the coronavirus outbreak, which in turn led to a drop in the general productivity rate. Hence, the study suggests the need for a corporate entity to change its supply model to improve productivity performance. In a similar vein, Machmuddah et al. (2020) assert that there was a significant difference in stock market prices and general growth performance before and after the COVID-19 spread in Indonesia. The stock market response to COVID-19 about the customers' goods sector was researched with an effect for open innovation, event study, and the comparison test. The study explores three months' daily stock prices before the outbreak (-90) and three months' daily stock prices after the pandemic (+90) totaling 2,670 observations across the two periods for a sum of 5,340 . That is, 5,340 and 2,670 represent the scale about estimated days before and after the disease outbreak. The results showed both hypothetical and applied inferences through the effective market assumption. Implying that the more accurate information is available to the investors, the better the market proficiently reacts to external shocks. The future gap was disclosed in the study by the researchers on the need to examine the long-term influence of an outbreak on the stock market performance.

Gormsen and Koijen (2020) predict a decline in economic output and dividends throughout the year 2020 because of the COVID-19 outbreak. The study adopted a forecasting model from aggregate stock market data based on the future dividend to measure investors' expectations. The study aimed at showing how the real forecast and bound change over time, across three major stocks markets: EU, Japan, and the US. Consequently, the trends of dividends dropped by $8 \%$ in Japan and the US, while a $14 \%$ decline is expected from the EU (as a result of COVID-19). Meanwhile, the expected growth in terms of output tends to fall by $2 \%$ both in the US and Japanese markets, while a 3\% decline in the EU market is expected. Hence, it is suggested that forward-looking and frequent-update measures are the keys for government and investors towards 
a sustainable economic growth path in the time of financial distress induced by the pandemic. Yan et al. (2020) submitted that the possible negative results of COVID-19 on the stock market could only be for the short-term while in the long run, the invisible hands of the market would normalize this potential adverse effect. The study models three US industrial sectors to justify their claims in the entertainment industry, technology industry, and travel industry. It was further stressed that a potential drop in profit due to a fall in price in those industries because of an outbreak could be eventually bought back in the long run. On the contrary, Falato et al. (2021) argued that US Federal Reserve actions helped in reducing adverse effects posed by the pandemic in the long run through funds transmission to the primary market. The study employed daily microdata to estimate major outflows to ascertain how the Federal Reserve liquidity base was used to trigger bond purchases that could contract outflows of fragile funds. They submitted that these Fed actions had paved the way for a new "bond fund fragility channel" where liquidity could transmit through bonds to the real sector of the US economy. Notably, Cox et al. (2020) corroborate the views of Falato et al. (2021) on the mitigating roles of the Federal Reserve in the time of the pandemic. The study used a dynamic pricing model to explain huge fluctuations in stock prices that are counter to risk aversion through announcements, outlined guidelines among others by the Apex Bank to boost the economy.

Ngwakwe (2020) reveals that the COVID-19 outbreak has a diverse influence on the global stock trade. The study employs a balancing t-test of difference in average stock prices at a dominant rate of five percent through three major regional market spots: Dow Jones Industrial Average in the USA, Euronext 100 data in Europe, and China's SSE Composite Index. Dow Jones Industrial Average disclosed a substantial decrease in average stock worth throughout the pandemic. The Chinese stock market's composite index showed a meaningful upsurge in average stock prices through the widespread of coronavirus, in which it is more sustainable than before the outbreak. Most decisions on stock market investment due to the pandemic are time-varying as more doses of vaccination are being rolled out, it is difficult to precisely predict stock market returns (Yu et al., 2021). On the contrary, to the other two markets indexes, Euronext 100 data revealed a non-significant change in the average price of stocks. Interestingly, the study provides the needed direction to stock market investors in identifying safer investment spots during the time of the COVID-19. Again, Baker et al. (2020) posit that the stock market witnessed an unprecedented reaction to COVID-19 because of government-imposed lockdown, which further affect the general performances of the US stock market. The study employed a text-based approach concerning daily stock market volatility and concluded further that the US stock market responded better to coronavirus outbreaks than previous infectious outbreaks in 1918-1919, 19571958, and 1968.

Interestingly, Takyi and Bentum-Ennin (2021) investigated the short-term effects of the novel corona outbreak on stock market productivity across thirteen African countries, through stock market data from daily time series, covering nine months. The study adopted Bayesian structural time series analysis (a state-space model) to evaluate the possible impact of the COVID-19 sickness on stock market output across the selected nations and the findings showed that stock market performances significantly drop throughout and after the incidence of the COVID-19 for about $-2.7 \%$ and $-21 \%$ respectively. Furthermore, the study concludes that there are restrictive effects of the outbreak on African's stock market growth. In a related study, Nwosa (2021) argued that COVID-19 had shown significant negative impacts than the world recession of 2009 and 2016 on stock market output, exchange rate, and oil price, with implications for transactional corporations and FDI inflow to Nigeria, using descriptive and causality techniques. The daily stock data used traversing from December 1, 2019, to May 31, 2020. More also, in the study, the causality test results disclosed that oil price granger cause exchange and stock market return whilst exchange rate granger cause stock market output. As a result, the paper inferred that COVID-19 portend adverse effects on stock market performance along with a negative impact on FDI inflow and transactional corporations in Nigeria.

Aremu et al. (2011) use component analysis to harmonize four different tools to form a single capital market index, where the control variable denotes market financial depth. The study reveals that 
there is an inverse link between economic growth and stock market development with the long-run term significant influence on the Nigerian economic growth. Meanwhile, Ajayi et al. (2018) revealed that the capital market has a long run significant influence on the Nigerian economic growth between 1985 and 2017, through Johansen cointegration, vector error model, and Granger Causality methods. Recently, after the emergence of the pandemic, a study conducted by Muhammad et al. (2020) tried to investigate the effects of the coronavirus surge on the stock market productivity through different statistical methods from Nigeria, China, Pakistan, the United Kingdom, Japan, Iran, Italy, the United State of America, and Spain. Those studies revealed that coronavirus had a negative impact on the socio-economic growth of the selected economies.

Given the above findings, although, the divergence views from the previous scholars informed this study so far, it is obvious that there have been scanty or few works on the effects of the coronavirus outbreak on the stock market and productivity level in South Africa, which is one of the worst-hit economies in the world. Again, the extent of the COVID-19 effects on financial activities among most countries had been of less focus in the literature particularly among emerging markets like South Africa. Consequently, this study aimed to investigate the effects of the new wave of COVID-19 on the financial market in South Africa with special consideration to twenty JSE listed companies.

The research hypothesis for this study is stated as follows:

H1: The new wave of COVID-19 has a positive effect on the financial market in South Africa.

\section{METHODOLOGY}

This study follows the fixed effect model developed by Paola and Maximilian (2020) to address the impact of daily infection of COVID-19 on stock exchange market return for the twenty JSE listed firms in South Africa over 90 days. Panel data regression method was adopted to ascertain the time-changing link between the returns and independent variables, by controlling for the firm-peculiar attribute. The fixed-effects model is appropriate for this model because FE possesses time-varying properties needed in a regression model. The functional relationship of the model is represented such that:

$$
\text { Return }=\int(\text { Covid }+ \text { DASPricing }+ \text { ExchR }) .
$$

However, the model of this magnitude must be implicit and time-varying, the introduction of a dynamic model is required such that:

$$
\begin{aligned}
& \text { Return }_{i t}=\alpha_{0}+\alpha_{1} \Delta \text { Return }_{i t-1}+ \\
& +\alpha_{2} \Delta \text { Covid }_{i t}+\alpha_{3} \Delta \text { DASPricing } \\
&
\end{aligned}
$$

where $\Delta$ Return is the changes in returns on stock for the 20 JSE listed firms, $\Delta$ represents it $-(i t-1)$ as the time lag in the model, this is required in the model since the past must explain the present. COVID-19 represents the daily infections rate over three consecutive months, DASPricing is the dividend-adjusted share pricing, ExchR proxy exchange rate and of course $\partial$ is the error term representing the uncaptured variable capable of exhibiting some missing variable biases and $i$ represents the number of cross-sections.

Data on daily infections of COVID-19 was sourced from Google online, returns on the stock market and dividend-adjusted share pricing were sourced from S\&P Capital IQ. The frequency of data is daily to allow for volatility variations for three months.

\section{RESULT}

This study used trend, descriptive and fixed-effect analysis, among others to examine the effect of coronavirus on South African stock market performance for ninety days, using data from stock market returns, adjusted share pricing, COVID-19, and exchange rate across twenty listed companies. This is to further unravel the extent to which each company's stock market returns reacted to COVID-19 during the period under review. Notably, the figures of data obtained from the twenty listed firms were grouped into five units, namely: Figures 1-4; Figures 5-8; Figures 9-12; Figures 13-16, and Figures 17-20 for comprehensive analysis. 
Source: Authors' computation.

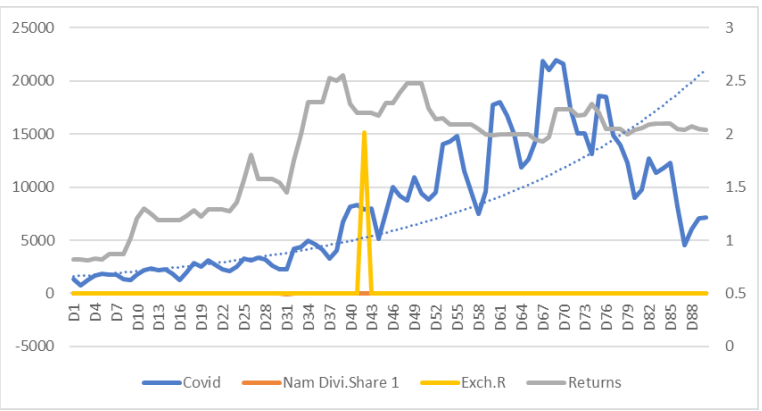

Figure 1. De-Chem Pharmacies Limited

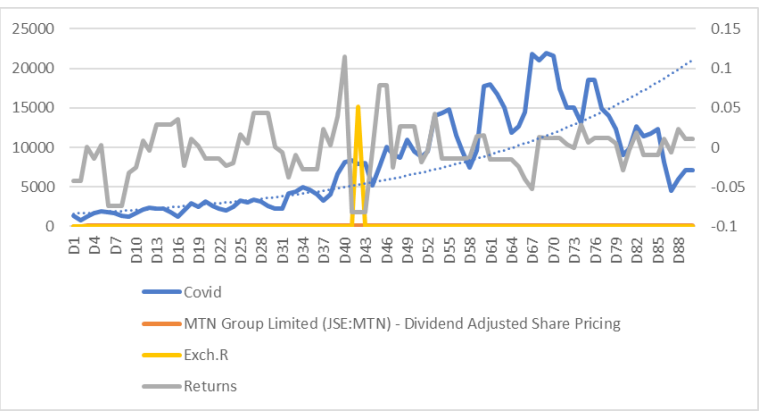

Figure 3. AngloGold Ashanty Limited

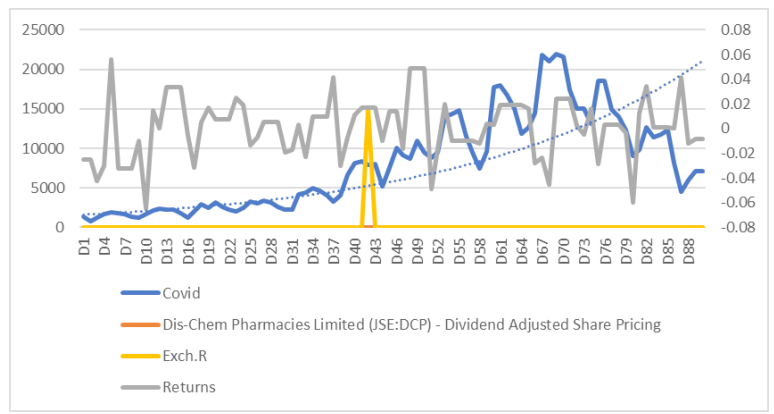

Figure 2. Nam Divi Share

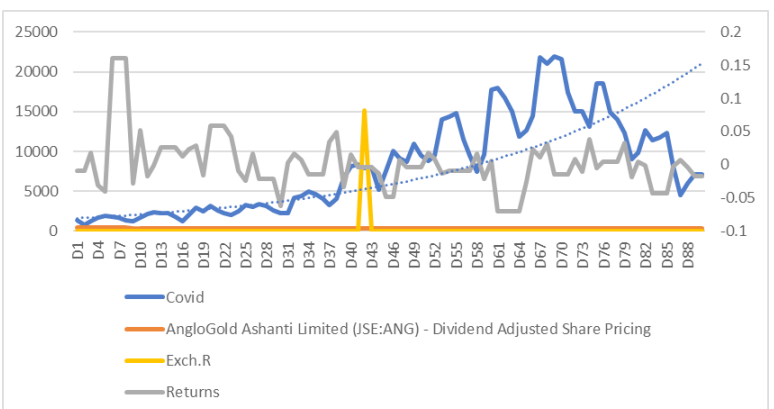

Figure 4. MTN Group Limited

Note: The vertical scales on the left-hand side measures the volume of stocks acquired by each listed company (thousands), while the vertical scales on the right-hand side capture the percentage returns from stocks (i.e., gains from stocks). The horizontal scales disclose the daily performances of each listed company with respect to their returns from stocks.

Figures1-4 represent data obtained from De-Chem Pharmacies Limited, Nam Divi Share, AngloGold Ashanty limited, and MTN group limited. It was shown that there was a spike in COVID-19 cases during the period under review and this exposed how the pandemic affected returns from the stock market of each firm. Notably, out of the first four listed companies, MTN group and AngloGold Ashanty limited were the worst-hit companies by the outbreak.

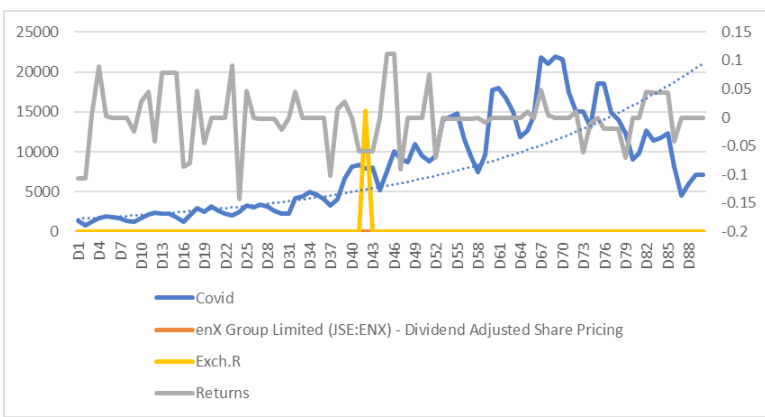

Figure 5. De Exxaro Resources Limited
Figures 5-8 represent data obtained from De Exxaro Resources Limited, Enx Group Limited, Impala Platinum Limited, and Momentum Metropolitan Holding Limited. The data further unravel the rise in pandemic cases with the disruptions in earnings of the registered companies. It is evident that Exxaro Resources Limited and Enx Group Limited show higher negative returns in stock towards the last twenty days. While the other two companies improved a bit towards the end of the periods under review.

Source: Authors' computation.

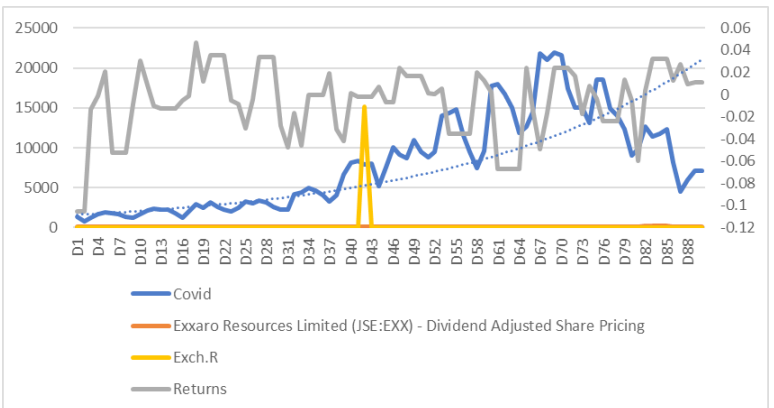

Figure 6. Enx Group Limited 
Source: Authors' computation.

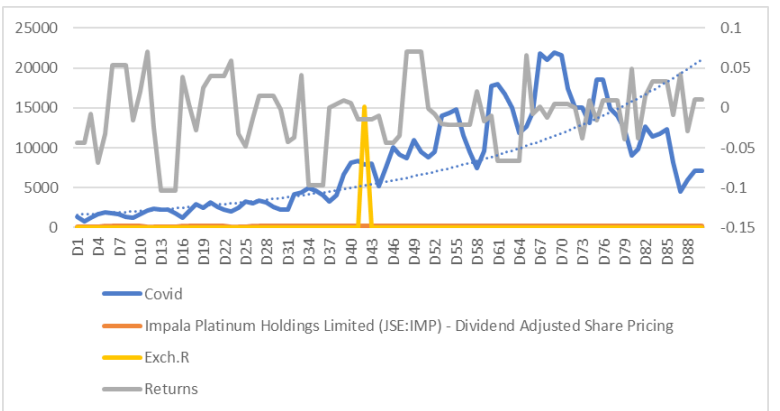

Figure 7. Impala Platinum Limited

Figures 9-12 explained data obtained from Mr. Price limited, Nampak Limited, Investec Bank Limited, and Sasol Limited. It is observed that the broken line denoted an exponential rise in COVID-19 incidences during the ninety days' periods. Meanwhile, Investec Bank Limited and Nampak limited showed resilient performances towards the last quarter of the period under review.

Moreover, Figures 13-16 capture data obtained from Santam Limited, Sappi Limited, Nedbank Group Limited, and Absa Group Limited were also used to reveal the effect of COVID-19 on South

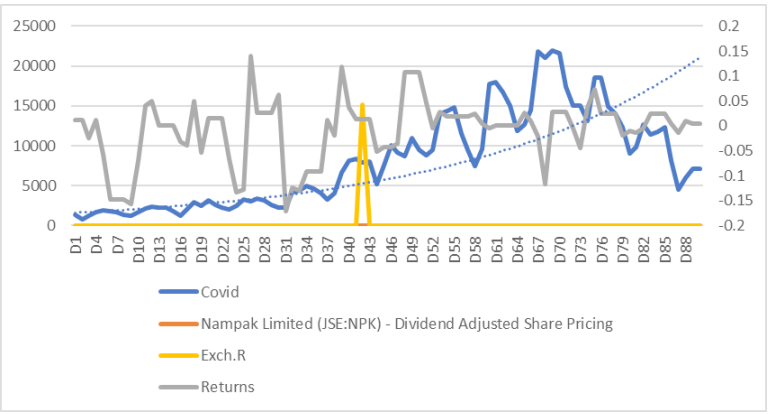

Figure 9. Mr. Price limited

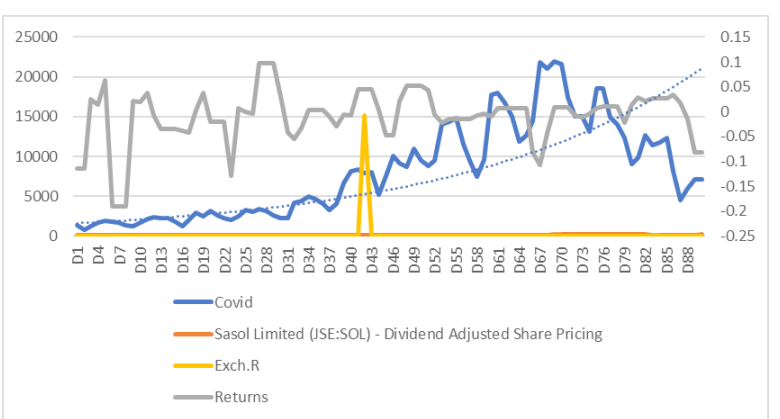

Figure 11. Investec Bank Limited

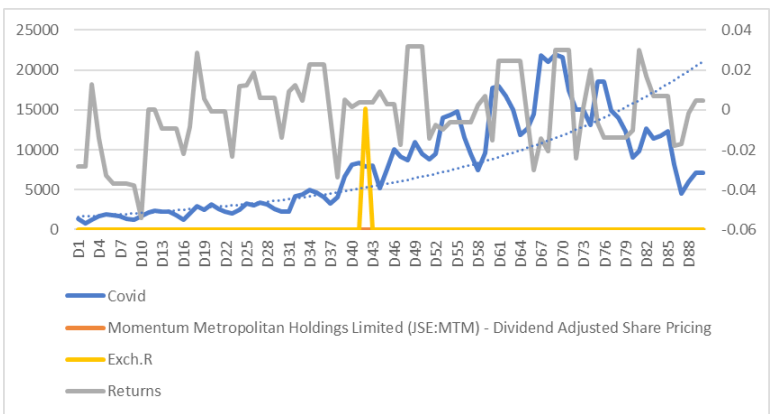

Figure 8. Momentum Metropolitan Holding Limited

African stock market output. Although in the initial days, the four companies in the category find it difficult to improve their performances they responded brilliantly towards the end of ninety days, especially Absa Group Limited that recorded the highest stock market returns.

Figures 17-20 cover data sourced from Acson Limited, Adapt IT Holdings Limited, Investec Bank Limited, and Bid Corporation Limited. Adapt IT Holdings Limited and Acson Limited were worst-hit companies with less than 1 percent of stock market returns two months after the pandemic outbreak, whereas Bid Corporation Limited

Source: Authors' computation.

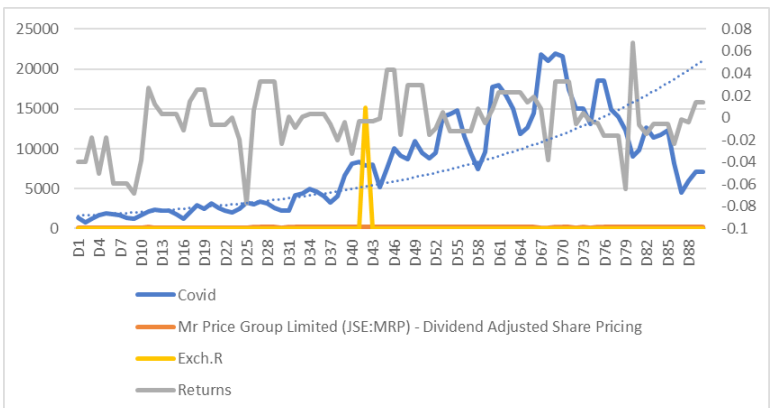

Figure 10. Nampak Limited

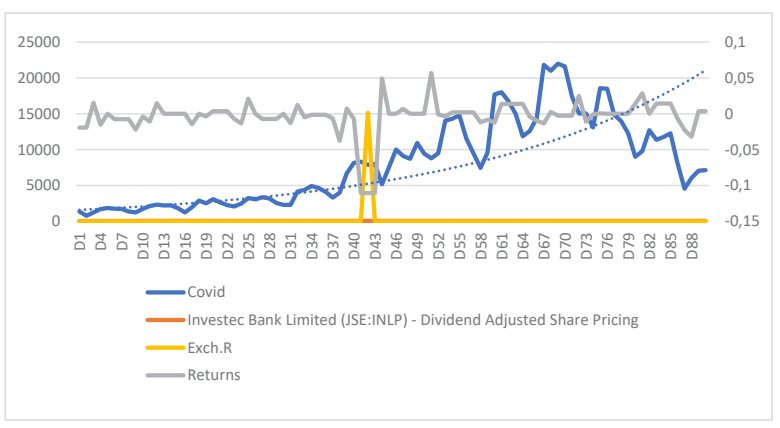

Figure 12. Sasol Limited 
Source: Authors' computation.

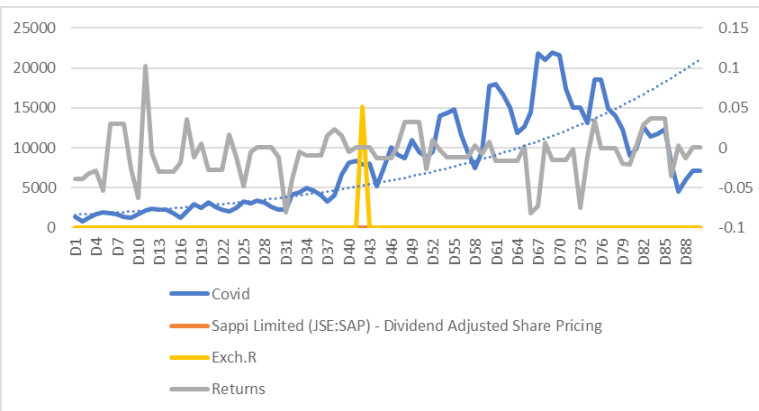

Figure 13. Santam Limited

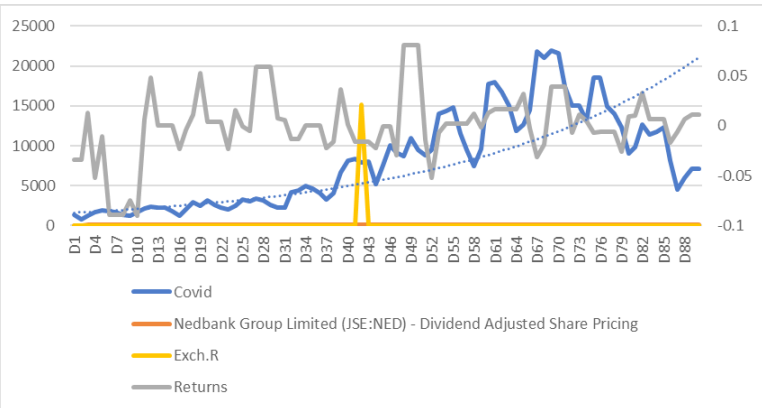

Figure 15. Nedbank Group Limited

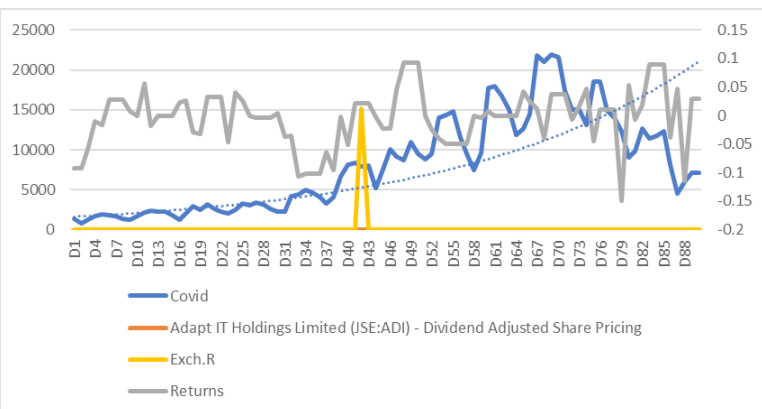

Figure 17. Acson Limited

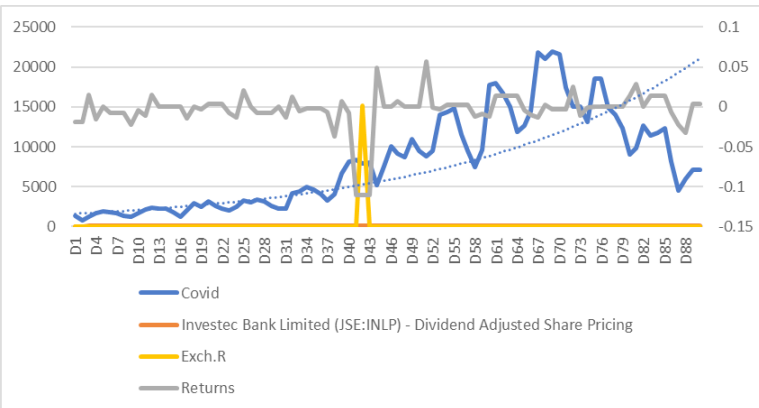

Figure 19. Investec Bank Limited

and Investec Bank Limited show more improved performances towards the end of the first 90 days despite their initial setbacks. Table 1 addresses the theoretical issues about the concept under investigation.

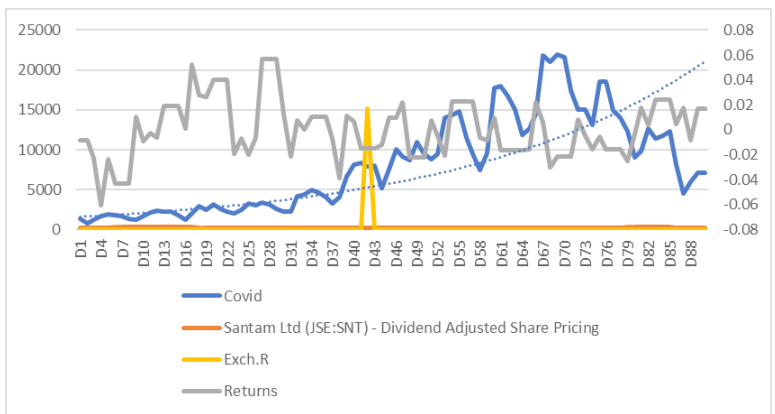

Figure 14. Sappi Limited

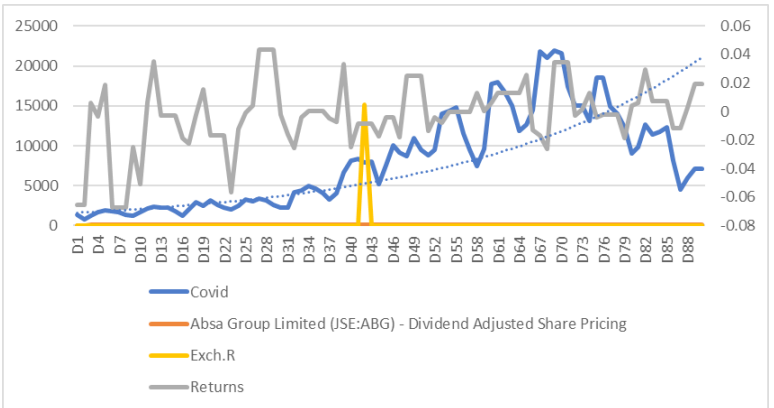

Figure 16. Absa Group Limited

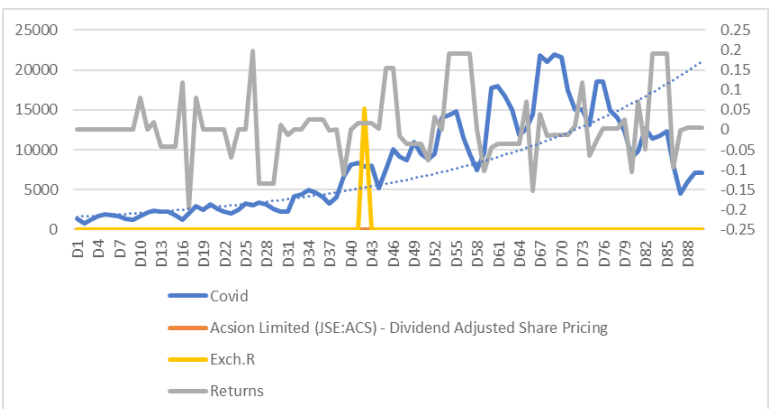

Figure 18. Adapt IT Holdings Limited

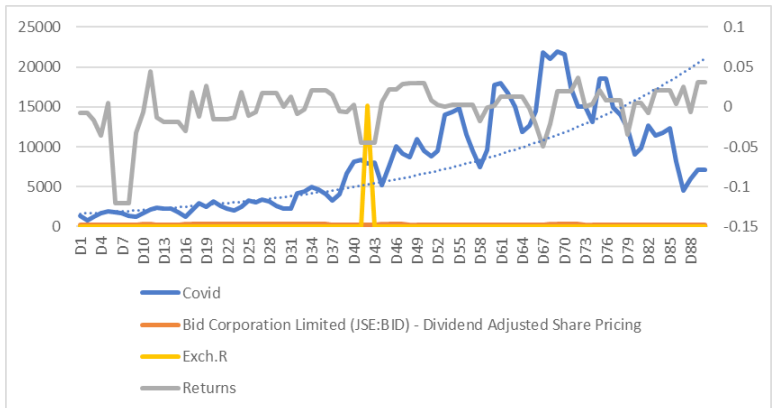

Figure 20. Bid Corporation Limited

To ensure that the multicollinearity problem does not emerge, panel correlation analysis was conducted and the result in Table 1 indicates the absence of multicollinearity. All variables exhibited weak association except the association between 
Table 1. Panel correlation matrix for all the twenty firms under investigation

\begin{tabular}{c|c|c|c|c}
\multicolumn{1}{c|}{ Variables } & Return & COVID-19 & Source: Authors' computation. \\
\hline Return & 1.0000 & - & - & ExchR \\
\hline COVID-19 & 0.0459 & 1.000 & - & - \\
\hline DAS Pricing & -0.2166 & 0.0310 & 1.000 & - \\
\hline ExchR & 0.0574 & 0.5053 & 0.0201 & 1.0000 \\
\hline
\end{tabular}

Table 2. Joint test for skewness/kurtosis tests for normality

Source: Authors' computation.

\begin{tabular}{l|c|c|c|c|c}
\hline \multicolumn{1}{c}{ Variables } & Obs & Mean $(\boldsymbol{\delta})$ & $\boldsymbol{P r}$ (Skewness) & $\boldsymbol{P r}$ (Kurtosis) & Prob > chi2 \\
\hline Returns & 1,800 & 0.0889 & 0.0000 & 0.0000 \\
\hline DAS Pricing & 1,800 & 100.9231 & 0.0000 & 0.0000 \\
\hline COVID & 1,800 & 8082.133 & 0.0000 & 0.0000 \\
\hdashline ExchR & 1,800 & .0659755 & 0.0046 & 0.0000 \\
\hline
\end{tabular}

Table 3. Fixed effects result on the series: DAS pricing, COVID-19, exchange rate, and return on the stock

\begin{tabular}{|c|c|c|c|c|c|}
\hline \multirow{2}{*}{\begin{tabular}{l}
\multicolumn{2}{c}{ Variables } \\
DAS Pricing
\end{tabular}} & \multirow{2}{*}{$\begin{array}{c}\text { Coefficients } \\
0.0004336\end{array}$} & \multirow{2}{*}{$\begin{array}{c}\text { Std. Err } \\
0.0002493\end{array}$} & \multirow{2}{*}{$\frac{P>|t|}{0.082}$} & \multicolumn{2}{|c|}{ [95\% Conf. Interval] } \\
\hline & & & & -.0000553 & 0.0009224 \\
\hline COVID-19 & $3.02 e-06$ & $4.83 e-07$ & 0.000 & $2.07 e-06$ & $3.97 e-06$ \\
\hline ExchR & 12.27302 & 6.915373 & 0.076 & -1.289998 & 25.83605 \\
\hline Constant & .0207683 & 0.0245243 & 0.397 & -0.0273313 & 0.0688679 \\
\hline
\end{tabular}

COVID-19 and exchange rates. The negative association between dividend-adjusted share pricing and stock market returns should be subjected to further investigation.

Mean averages among others are one of the measures of central tendencies and for the normality test, Table 3 showcases the result on skewness and kurtosis with strong probability values. The nearness to zero indicates a well-fitted model. The skewness and kurtosis indicated that the study's model was normally distributed and skewed.

Table 3 shows the result from fixed effects analysis. It is clear from the table that the new wave of COVID-19 has a positive effect on the stock market in South Africa. This is evidenced with the significant P-value and positive coefficient indicating a positive link between COVID-19 daily infections and returns on the stock market.

\section{DISCUSSION}

The result in Table 3 showcases the fixed effects analysis of COVID-19 infections on the stock market returns of the 20 JSE listed companies in
South Africa over 90 days. The November 2020January 2021 period represents a period of the new wave of COVID-19 infections. The result from Table 3 shows a positive link between COVID-19 daily infections and returns on the stock market within the range of three months period under investigation. Activities such as sales of stock at the stock market during the new wave of COVID-19 were not put-on hold in South Africa, which could account for the positive relationship. However, the coefficient value of 0.00000302 in effect is an indication of a very weak relationship, indicating a slow velocity of movement during this era. Any unit increase in the possible outbreak of COVID-19 when financial activities were allowed to co-exist together would cause returns on stock to increase by 0.00000302 . Besides, both dividends adjusted share pricing and the exchange rate had a significant rise during the period under investigation. This result negates the findings of Takyi and Bentum-Ennin (2021) and Nwosa (2021) whose results unanimously agree on the inverse relationship of the COVID-19 outbreak with financial market activities. This period performed better than the period of lockdown. For instance, the market during lockdown performed poorly in the South African market, both the Johannesburg 


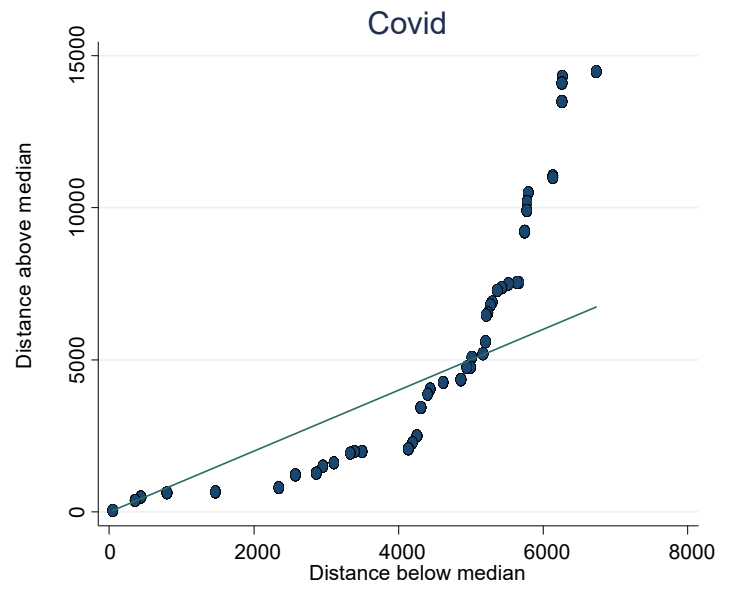

Figure 21. COVID-19 data

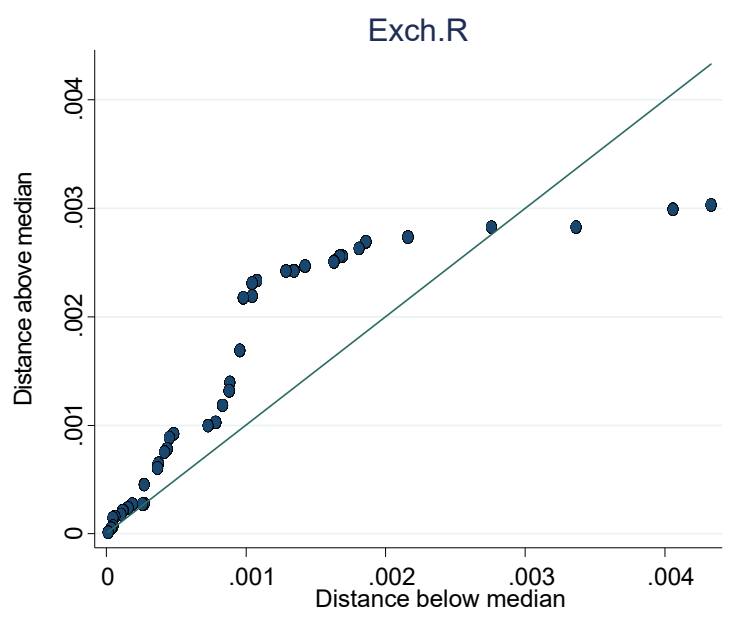

Figure 23. Exchange rate

stock exchange (JSE) all share index started to fall by the end of February and two weeks later, the S\&P 500 began to decline. In particular, the report indicated that the all-share index (ALSI) top 40 had a steady decline on February 13, 2020 immediately after South Africa's State of the Nation Address. Total losses reported were close to $35 \%$ since January 2, 2020. The volume of trade initially spiked by the end of February 2020 as markets dived into a state of panic. Exchange rate volatility was also not in favor of the South African market during the lockdown. South African market currencies weakened drastically against the US Dollar as investors considered these currencies as risky in an already volatile market. Rand in South African declined to a more than four-year low during the period but eventually appreciated when restrictions were eased as COVID-19 gradually declined. Other commodities market was also affected by COVID-19 as deterioration

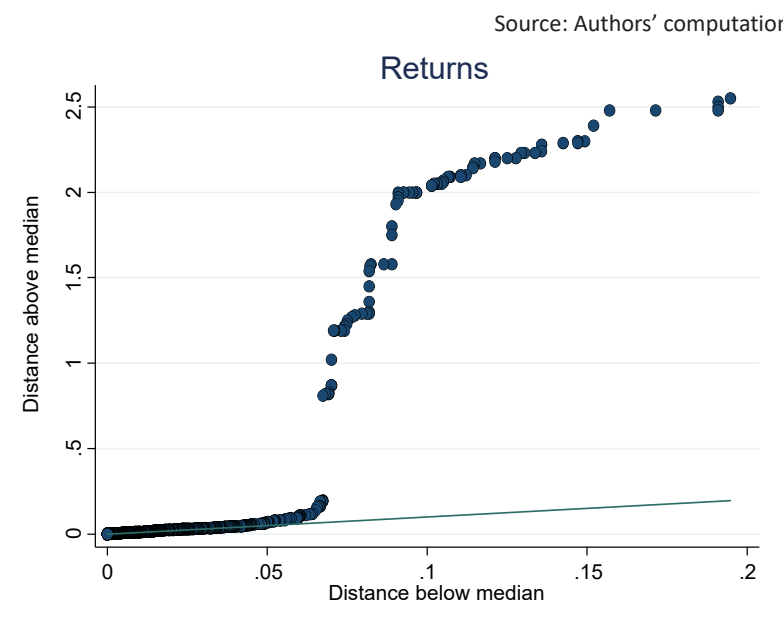

Figure 22. Stocks returns

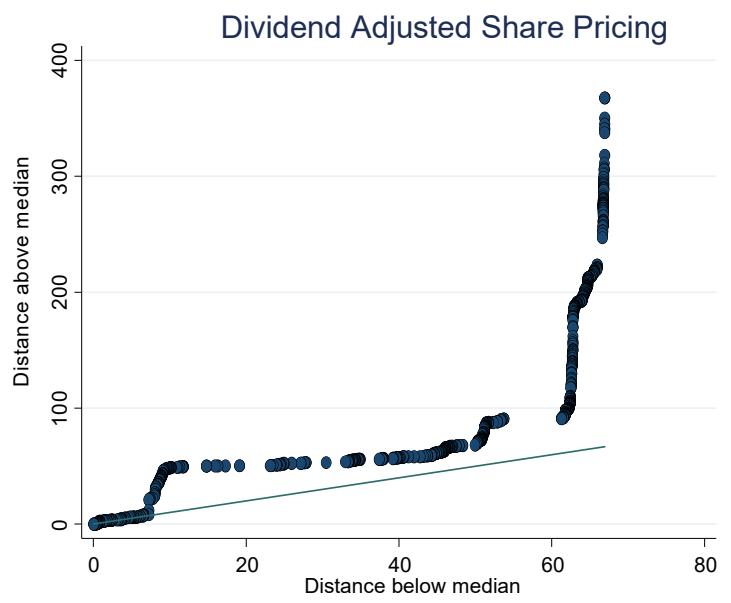

Figure 24. Dividend adjusted share pricing

in the spot price was observed for metals such as platinum and aluminum. In March 2020, the spot price on platinum lost 45 percent of the total value, the lowest in 17 years.

The paper further addresses the distributive link between the COVID-19 daily infection rate and associated returns on stock, exchange rates, and dividend-adjusted share pricing respectively. These constitute the variables under observation. The trend of the relationship result is graphically illustrated in Figures 21-24, which show the symmetry plotted graphs showing the relationship among COVID-19 contractions, the returns on the stock market, exchange rates, and dividend-adjusted share pricing among the 20 JSE listed companies.

Figures 21-24 exhibit a distribution in the line of symmetric with data on both sides of the median confirming that all variables in the mod- 
el were distributed the same way. It simply implied that the tails of the distribution are mirror images of reality. The symmetry plot graphs the upper distance of the median on the $\mathrm{x}$-axis vis-a-vis the lower distance to the median on the $y$-axis, for each data point. The graph truly reflected the increasing trend in the COVID-19 pandemic alongside this upward movement in the dynamics of association with financial activities.

\section{CONCLUSION}

This paper aimed to examine the effects of the new wave of COVID-19 on the financial market with data from the twenty JSE listed companies in South Africa. Robust descriptive analysis with plotted median distributive graph and fixed effects time-variant analysis was adopted as the estimating techniques. The result from trend analysis was based on the stock's return performances across the twenty South African listed companies. From the result, Chem Pharmacies Limited, Nam Divi Share, AngloGold Ashanty Limited, MTN Group Limited, Sasol Limited, Adapt IT Holdings Limited, and Acson Limited were the worst-hit companies with less than 1 percent of stock market returns into two months of the pandemic outbreak. While Exxaro Resources Limited, Enx Group Limited, Investec Bank Limited and Nampak Limited, Santam Limited, Sappi Limited, and Nedbank Group Limited stock returns dropped sharply at the first twenty days of the pandemic and later showed resilient towards the last fifteen days under review. Interestingly, Momentum Metropolitan Holding Limited, Impala Platinum Limited, Mr. Price Limited, Absa Group Limited, Bid Corporation Limited and Investec Bank Limited were better off in their stock returns, with more improved performances towards the end of the first month despite their first ten days shocks.

Again, the result of the fixed effects showed a positive but sluggish link between the daily incidences of infectious COVID-19 and returns on the stock market adjusted share pricing. Any unit increase in the possible outbreak of COVID-19 when financial activities were allowed to co-exist together caused returns on stock to increase by 0.00000302 . Further, returns on stock also increase by 0.0004336 as a result of a unit increase in stock market adjusted share pricing. This positive relationship indicates that both COVID-19 pandemic and financial activities were made to co-move together in South African thereby restricting the COVID-19 pandemic from impacting negatively on financial activities at the period of investigation. It is axiomatic from the result of trend and fixed effects analysis that firms respond to market shocks differently during the COVID-19 pandemic. Consequently, government policies on lockdown may be viewed from various perspectives of market behavior as total lockdown of the economy during COVID-19 may not be the most appropriate approach to financial intervention in the interest of the national economy in South Africa.

\section{AUTHOR CONTRIBUTIONS}

Conceptualization: Gbenga Wilfred Akinola, Keji Sunday Anderu.

Data curation: Gbenga Wilfred Akinola.

Formal analysis: Gbenga Wilfred Akinola.

Investigation: Gbenga Wilfred Akinola, Josue Mbonigaba.

Methodology: Gbenga Wilfred Akinola, Josue Mbonigaba.

Project administration: Josue Mbonigaba.

Software: Keji Sunday Anderu.

Supervision: Josue Mbonigaba.

Validation: Keji Sunday Anderu, Josue Mbonigaba.

Visualization: Keji Sunday Anderu.

Writing - original draft: Gbenga Wilfred Akinola.

Writing - review \& editing: Gbenga Wilfred Akinola. 


\section{REFERENCES}

1. Ajayi, O. O., Abina, P. A., \& Ijomah, N. C. (2018). Empirical Analysis on the Relationship between Capital Market and Economic Growth in Nigeria. Journal of Asian Business Strategy, 8(2), 15-26. Retrieved from https://ideas.repec. org/a/asi/joabsj/2018p15-26.html

2. Anderu, K. S. (2020). Capital market and economic growth in Nigeria. Jurnal Perspektif Pembiayaan dan Pembangunan Daerah, 8(3), 295-310. https://doi. org/10.22437/ppd.v8i3.9652

3. Aremu, O. S., Suberu, O. J., \& Ladipo, O. O. (2011). Impact of the Nigerian capital market operations on the local investments in Nigeria. Journal of Research in International Business Management, 1(8), 258-261. Retrieved from https:// www.interesjournals.org/articles/ impact-of-the-nigerian-capitalmarket-operations-on-the-localinvestments-in-nigeria.pdf

4. Baker, S. R., Bloom, N., Davis, S. J., Kost, K. J., Sammon, M. C., \& Viratyosin, T. (2020). The unprecedented stock market impact of COVID-19 (Working paper No. 26945). Cambridge, Massachusetts: National Bureau of Economic Research. Retrieved July 7, 2021, from http://www.nber. org/papers/w26945

5. Chen, M. H., Jang, S. S., \& Kim, W. G. (2007). The impact of the SARS outbreak on Taiwanese hotel stock performance: an eventstudy approach. International Journal of Hospitality Management, 26(1), 200-212. https://dx.doi. org/10.1016\%2Fj.ijhm.2005.11.004

6. Chen, M. P., Lee, C. C., Lin, Y. H., \& Chen, W. Y. (2018). Did the SARS epidemic weaken the integration of Asian stock markets? Evidence from smooth time-varying cointegration analysis. Economic researchEkonomska istraživanja, 31(1), 908-926. https://doi.org/10.1080/1 331677X.2018.1456354

7. Cox, J., Greenwald, D. L., \& Ludvigson, S. C. (2020). What Explains the COVID-19 Stock
Market? (Working Paper

No. 27784). Cambridge,

Massachusetts: National Bureau

of Economic Research. https://doi. org/10.3386/w27784

8. Davis, S. J., Liu, D., \& Sheng, X. S. (2021). Stock Prices, Lockdowns, and Economic Activity in the Time of Coronavirus (Working Paper No. 2020-156). Becker Friedman Institute for Economics, the University of Chicago. http:// dx.doi.org/10.2139/ssrn.3714028

9. El-Wassal, K. A. (2013). The Development of Stock Markets: In Search of a Theory. International Journal of Economics and Financial Issues, 3(3), 606-624. Retrieved from https://ideas.repec.org/a/eco/ journ1/2013-03-6.html

10. Falato, A., Goldstein, I., \& Hortaçsu, A. (2021). Financial Fragility in the COVID-19Crisis: The Case of Investment Funds in Corporate Bond Markets. Journal of Monetary Economics. https://doi.org/10.1016/j.jmoneco.2021.07.001

11. Gormsen, N. J., \& Koijen, R. S. J. (2020). Coronavirus: Impact on Stock Prices and Growth Expectations (Working Paper No. 2020-22). Becker Friedman Institute for Economics, the University of Chicago. http:// dx.doi.org/10.2139/ssrn.3555917.

12. Horowitz, J. (2020, February 9). Investors shouldn't be complacent about the coronavirus threat. CCN. Retrieved from https://edition.cnn. com/2020/02/09/investing/stocksweek-ahead/index.html

13. Lanchimba, C., Bonilla-Bolaños, A., \& Díaz-Sánchez, J. P. (2020). The COVID-19pandemic: theoretical scenarios of its socioeconomic impacts in Latin America and the Caribbean. Brazilian Journal of Political Economy, 40(4), 622-646. https:// doi.org/10.1590/0101-315720203199

14. Machmuddah, Z., Utomo, S. D., Suhartono, E., Ali, S., \& Ghulam, W. A. (2020). Stock Market Reaction to COVID-19:
Evidence in Customer Goods Sector with the Implication for Open Innovation. Journal of Open Innovation: Technology, Market, and Complexity, 6(4), 99. https:// doi.org/10.3390/joitmc6040099

15. Muhammad, Z., Palwasha, J., Junaid, S., \& Muhammad, S. (2020). Effects and catastrophe of COVID-19on corporate \& financial sector. International Journal of Creative \& Innovation Sciences July-December, 1(2), 43-57.

16. Ngwakwe, C. C. (2020). Effect of COVID-19Pandemic on Global Stock Market Values: A Differential Analysis. Acta Universitatis Danubius. Economica, 16(2). Retrieved from https://dj.univ-danubius.ro/index. php/AUDOE/article/view/258

17. Nwosa, P. I. (2021). Oil price, exchange rate, and stock market performance during the COVID-19 pandemic: implications for TNCs and FDI inflow in Nigeria. Transnational Corporations Review, 13(1), 125 137. https://doi.org/10.1080/19186 444.2020.1855957

18. OECD. (2020). The Impact of the Coronavirus (Covid-19) Crisis on Development Finance. Retrieved from http://www.oecd.org/ coronavirus/policy-responses/ the-impact-of-the-coronaviruscovid-19-crisis-on-developmentfinance-9de00b3b/

19. Paola, O., \& Maximilian, D. W. (2020). COVID-19 and financial markets: Assessing the impact of the coronavirus on the Eurozone (Economic Paper No. 859). RWI - Leibniz-Institut für Wirtschaftsforschung, Ruhr-University Bochum, TU Dortmund University, University of Duisburg-Essen. Retrieved from https://ideas.repec. org/p/zbw/rwirep/859.html

20. PWC. (2021). Financial Markets of Covid-19. Price water houses cooper. Retrieved from https:// www.pwc.co.za/en/issues/covid-19.html 
21. Takyi, P. O., \& Bentum-Ennin, I. (2021). The impact of COVID19on stock market performance in Africa: A Bayesian structural time series approach. Journal of economics and business, 115, 105968. https://doi.org/10.1016/j. jeconbus.2020.105968

22. The Telegraph. (2020). \$1 trillion wiped off global stock markets amid coronavirus panic.
23. Theriou, N., Vassilios, A., \& Dimitrios, M. (2006). Testing the Relation between Risk and Returns using CAPM and APT: The Case of Athens Stock Exchange (ASE). $4^{\text {th }}$ International Conference on Accounting and Finance in Transition. Adelaide, Australia.

24. Yan, H., Tu, A., Stuart, L., \& Zhang, Q. (2020). Analysis of the
Effect of COVID-19 On the Stock Market and Potential Investing Strategies. Gies School of Business, University of Illinois Urbana Champaign

25. Yu, X., Xiao, K., \& Liu, J. (2021) Dynamic co-movements of COVID-19 pandemic anxieties and stock market returns. Finance Research Letters, 102219. https:// doi.org/10.1016/j.frl.2021.102219 